\author{
Magdalena VAVERKOVÁ ${ }^{*}$, František TOMAN ${ }^{1}$, Dana ADAMCOVÁ ${ }^{1}$ \\ and Jana KOTOVICOVÁ ${ }^{1}$
}

\title{
STUDY OF THE BIODEGRABILITY \\ OF DEGRADABLE/BIODEGRADABLE PLASTIC MATERIAL IN A CONTROLLED COMPOSTING ENVIRONMENT
}

\author{
BADANIE BIODEGRADACJI ROZKLADALNYCH/BIODEGRADOWALNYCH \\ TWORZYW SZTUCZNYCH W KONTROLOWANYCH WARUNKACH \\ KOMPOSTOWANIA
}

\begin{abstract}
The objective of this study was to determine the degrability/biodegradability of disposable plastic bags available on the market that are labeled as degradable/biodegradable and those certified as compost. The investigated materials were obtained from chain stores in the Czech Republic and Poland. Seven kinds of bags (commercially available) were used in this study. One of them was a disposable bag made of HDPE and mixed with totally degradable plastic additive (TDPA additive). Another was a disposable made of polyethylene with the addition of pro-oxidant additive $\left(\mathrm{d}_{2} \mathrm{~W}\right.$ additive). One was labeled as $100 \%$ degradable within various periods of time, from three months up to three years, and four were certified as compostable. The test was carried out in a controlled composting environment. The biodisintegration degree of the obtained pieces was evaluated following a modified version of CSN EN 14806 Norm "Packaging - Preliminary evaluation of the disintegration of the packaging materials under simulated composting conditions in a laboratory scale test" and a modified version of ČSN EN ISO 20200 "Plastics - Determination of the degree of disintegration of plastic materials under simulated composting conditions in laboratory-scale test" (ISO 20200:2004). The emphasis was put on determination whether the bags are degradable/biodegradable or not.
\end{abstract}

Keywords: biodegradability, compostability, degradation, controlled environment

\section{Introduction}

The development of the chemical process for manufacturing synthetic polymers (plastics) from crude oil was a breakthrough in chemistry and in material sciences, and it paved the way to the production of one of the most versatile groups of materials ever produced. These new materials combined features exhibiting strength, flexibility, light weight, and easy and low-cost production. However, these materials were found to be extremely durable and were considered among the most non-biodegradable synthetic

\footnotetext{
${ }^{1}$ Department of Applied and Landscape Ecology, Faculty of Agronomy, Mendel University in Brno, Zemědělská 1, 61300 Brno, Czech Republic, phone +420 545132484

*Corresponding author: magda.vaverkova@uake.cz
} 
materials. These traits facilitated the application of plastics to almost any industrial, agricultural or domestic market. The most consumed synthetic polymer is polyethylene (PE), with a current global production of ca 140 million $\mathrm{Mg}$ (tons) per year [1]. Plastics production exceeds 180 million $\mathrm{Mg}$ (tons) per year, with a yearly increase in supply and demand. These plastics turn to solid waste after their end of life and will accumulate in the environment. Hence, from an environmentally friendly point of view, the production of biodegradable plastics is important to reduce the accumulation of plastic waste in the environment [2]. Petroleum-based plastic products are characterized as not easily degradable because of their relatively high stability and hydrophobic characteristics [2]. Plastics are inert (that is, resistant to biodegradation), durable, hygienic, lightweight, cheap, and malleable. However, the main environmental disadvantage of plastics materials is that they do not readily break down in the environment and therefore can litter the natural environment [3]. Consequently, considerable attention has been given to the development of degradable plastics materials derived from agricultural resources or, alternatively, to petroleum-based plastics modified with degradable additives. Degradation is an important process in the environmental breakdown of polymer substrate into organic waste. For biodegradable materials, composting is being used as an alternative technology to conventional disposal in landfills or incineration. By this process, biodegradable wastes or organic material are transferred into humic substances, which are valuable as a high quality fertilizer for agricultural proposes [4].

The relatively high number of reports describing the biodegradability of a wide range of plastics may lead to the incorrect conclusion that most plastic polymers can be readily biodegraded. In fact, in terms of amounts, the production of the polymers PE and polystyrene (PS) is, by far, greater than that of the rest of the other plastic compounds that are considered biodegradable. Furthermore, not all types of degradable plastics are destroyed completely in natural environments, raising the question of the definition of biodegradable [1].

\section{Literature review}

When biodegradable plastics started entering the market, there were a series of misconceptions about the term degradable and biodegradable. Many plastics labeled biodegradable entered the market, but only disintegrated and did not completely biodegrade. These plastics have been commercially available since 1990 and can be either of plant origins, such as starch, or are produced by bacteria. Therefore, in order to avoid misconceptions, several standards in the area of degradable as well as biodegradable plastics have been developed by national standard bodies [5].

Standards have been developed by American Society for Testing Materials (ASTM) and International Standards Organization (ISO) for the assessment of the biodegradability of polymers in different environments, such as composting, anaerobic digestion, and wastewater treatment. According to ASTM standard D6400, a product is compostable if it passed the tests of disintegration, biodegradation, and terrestrial and aquatic safety in controlled laboratory-scale composting. Similarly, there is a standard developed by ISO (EN 13432) specifically for packaging, which assesses packaging compostability based on characterization, biodegradation, disintegration, and quality of compost or ecotoxicity. Characterization of packaging includes analysis of the composition of package materials: heavy metals and organic carbon content, total dry solids and volatile content [6]. 
A number of certification systems that provide compostable packaging labels have been established worldwide for certification of compostable plastics. Some of these labels are based on standards developed by ASTM, ISO, Deutsches Institut für Normung (DIN), and Japanese Industrial Standards (JIS). These certification systems include "DIN CERTCO" based on DIN EN 13432, "OK Compost" by AIB Vincotte (Belgium) based on EN 3432, "Compostable" by the U.S. Composting Council based on ASTM D6400, and the "GreenPla" certification by the Biodegradable Plastics Society (Japan) based on JIS K6953, to mention a few. JIS K6953 is reported by the Japanese Industrial Standards Committee to be identical to ISO 14855 [6].

According to ASTM D6400-04 a biodegradable plastic is "a plastic that degrades because of the action of naturally occurring microorganisms such as bacteria, fungi, and algae", and a compostable plastic is "a plastic that undergoes degradation by biological processes during composting to yield carbon dioxide, water, inorganic compounds, and biomass at a rate consistent with other known compostable materials and leaves no visually distinguishable or toxic residues". Standards developed by ASTM and ISO are used to assess the biodegradability of biodegradable plastics in different environments, such as composting, anaerobic digestion, and wastewater treatment. In order to fulfill a cradle-to-cradle approach, one of the most attractive alternatives besides reusing and recycling would be to have biodegradable plastics composted at the end of their useful life and later used in sustainable agricultural practices. For this scenario, addressing the efficiency of the plastic's biodegradability process becomes essential [7].

Guillet defined biodegradable polymers as being capable of being chemically transformed by the action of biological enzymes or microorganisms into products that themselves are capable of further biodegradation [8].

\section{Single-use plastic bags}

Plastic bags are a common means of carrying merchandise. In the Czech Republic and Poland, retailers, markets, and shops distribute these bags intended to be used once, predominantly free of charge. After being used to carry goods from retailers to homes, most of the bags are disposed of or stored for reuse; in either case, they eventually reach landfills. Many chain stores in the Czech Republic, Poland and other eastern European countries have introduced degradable/biodegradable plastics and have suggested that consumers avoid conventional plastic shopping bags. An increasing number of products labeled with the terms "environmentally friendly", "degradable", "bio-", "green-", "biobased", and "biodegradable" are being developed as promising solutions to litter "simply disappearing". "Single-use" bags certified as compostable have been appearing on the market in recent years.

\section{Compostable plastics}

Compostable polymers are being promoted as environmentally beneficial, especially if they can be derived from renewable resources and recovered through organic recycling. There are two main factors that make a material compostable: the material itself and the microorganisms in the compost. The material must be biodegradable, such as paper/paperboard and biodegradable polymers, which can be consumed by microorganisms as food sources. A compost pile is a great source of microbial activity, because it has a high moisture content and temperature, so it is a suitable environment for a variety of microbes, 
such as bacteria and fungi, to live and reproduce. This in turn provides a tremendous amount and variety of organisms able to attack and digest compostable materials. Bacteria can be either aerobic or anaerobic, while fungi are strictly aerobic. In both cases, the degradative reaction proceeds by production of enzymes that break down organic substrates to provide nutrients [6].

\section{Composting of biodegradable plastics}

Biodegradability is tied to a specific environment. For instance, the usual biodegradation time requirement for bioplastic to be composted is 1 to 6 months [9]. For some polymers, a relatively high temperature is necessary to initiate the degradation process. The degradability of a biodegradable plastic depends not only on the specific kind of plastic but also on the operational conditions of the composting process, such as temperature and the kind of inoculum used [10]. In North America and Europe, the composting infrastructure is a key feature in the ultimate disposal of biodegradable polymers. In Europe, some countries allow the addition of paper and biodegradable polymers to the biowaste fraction [11]. Wilde and Boelens [12] have proposed three characteristics of bioplastics and/or paper that would render them suitable for use in composting and organic recovery. These characteristics are biodegradation, disintegration and no effect on compost quality.

The objective of this study was to determine the degradability (biodegradability) of 'single-use' plastic bags available on the market that are labeled as degradable/biodegradable and 'single-use' plastic bags certified as compostable. The test was carried out in a controlled composting environment. The project length was 12 weeks. The emphasis was put on discovering whether the bags are degradable/biodegradable or not.

\section{Experimental procedures}

\section{Bioplastic materials}

The investigated degradable/biodegradable materials were obtained from chain stores in the Czech Republic and Poland. Seven kinds of degradable/biodegradable bags (commercially available) were used in this study and cellulose filter paper as a positive control (reference mixture).

Table 1

Amounts of synthetic waste and plastic pieces placed in each reactor

\begin{tabular}{|c|c|c|c|c|}
\hline Sample & Type & Description & $\boldsymbol{M}_{\boldsymbol{i}}{ }^{*}$ sample [g] & m substrate [g] \\
\hline 1 & N/A & BIO-D Plast & 3.5 & 1000 \\
\hline 2 & HDPE+TDPA & $100 \%$ degradable & 7.02 & 1000 \\
\hline 3 & N/A & $100 \%$ degradable & 7.03 & 1000 \\
\hline 4 & Starch & Compostable 7P0147 & 7.01 & 1000 \\
\hline 5 & Starch and Polycaprolactone & $\begin{array}{c}\text { OK Compost AIB } \\
\text { VINCOTTE }\end{array}$ & 7.02 & 1000 \\
\hline 6 & N/A & Compostable 7P0202 & 7.01 & 1000 \\
\hline 7 & Natural material & Compostable 7P0073 & 7.02 & 1000 \\
\hline 8 & Cellulose (blank) & - & 7.02 & 1000 \\
\hline
\end{tabular}

${ }^{*} M_{i}$ - initial dry mass of plastic material 
One of them was a carrier bag or a "shopper-bag" made of high degradable polyethylene (HDPE) and mixed with totally degradable plastic additive (TDPA additive). Another was a carrier bag or a "shopper-bag" made of polyethylene with the addition of pro-oxidant additive $\left(\mathrm{d}_{2} \mathrm{~W}\right.$ additive $)$. One was labeled as $100 \%$ degradable within various periods of time, from three months up to three years, and four were certified compostable. The amounts of synthetic waste and plastic pieces placed in each reactor are listed in Table 1.

\section{Disintegration tests}

The degree of disintegration of the pieces obtained was evaluated following modified version of CSN EN 14806 Norm "Packaging - Preliminary evaluation of the disintegration of the packaging materials under simulated composting conditions in a laboratory scale test" and a modified version of CSN EN ISO 20200 "Plastics - Determination of the degree of disintegration of plastic materials under simulated composting conditions in a laboratory-scale test" (ISO 20200:2004). According to these tests, the plastic pieces obtained were mixed with a solid biodegradable synthetic material and subjected to aerobic degradation. However, the composition of the synthetic material was changed as follows (as percentage of dry mass): $51 \%$ compost, $4 \%$ wood sawdust, $44 \%$ biodegradable municipal waste, and $1 \%$ glucose. This modification was undertaken in order to bring the test nearer to real conditions and is based on research on the monthly production of biodegradable waste in twenty families.

For each tested material two reactors were prepared following the CSN EN 14806 Norm. It is a modification compared with the CSN EN ISO 20200 Norm which requires minimum of three reactors for each tested sample. The CSN EN 14806 Norm states as useful for the control of the development in the reactor in which the composting takes place to undertake a blind experiment without the tested material. The authors modified the procedure stated in the Norm and in order to safeguard the presence of suitable conditions for biodegradation filter paper was used. The control of humidity was carried out under the CSN EN 14806 Norm, not according to the CSN EN ISO 20200.

Table 2

Characteristics of the compost

\begin{tabular}{|c|c|c|}
\hline Parameters & Value & Unit \\
\hline Moisture & $30 \div 65$ & {$[\%]$} \\
\hline Combustibles & min. 20 & {$[\%]$} \\
\hline Total nitrogen & min. 0.6 & {$[\%$ d.m. $]$} \\
\hline $\mathrm{pH}$ & $6.0 \div 8.5$ & {$[\%]$} \\
\hline Undecomposable ingredients & max. 2.0 & {$[\mathrm{mg} / \mathrm{kg}]$} \\
\hline $\mathrm{C}: \mathrm{N}$ & max. 30 & {$[\mathrm{mg} / \mathrm{kg}]$} \\
\hline $\mathrm{Cd}$ & 2 & {$[\mathrm{mg} / \mathrm{kg}]$} \\
\hline $\mathrm{Pb}$ & 100 & {$[\mathrm{mg} / \mathrm{kg}]$} \\
\hline $\mathrm{Hg}$ & 1 & {$[\mathrm{mg} / \mathrm{kg}]$} \\
\hline $\mathrm{As}$ & 20 & {$[\mathrm{mg} / \mathrm{kg}]$} \\
\hline $\mathrm{Cr}$ & 100 & {$[\mathrm{mg} / \mathrm{kg}]$} \\
\hline $\mathrm{Mo}$ & 20 & {$[\mathrm{mg} / \mathrm{kg}]$} \\
\hline $\mathrm{Ni}$ & 50 & {$[\mathrm{mg} / \mathrm{kg}]$} \\
\hline $\mathrm{Cu}$ & 150 & \\
\hline $\mathrm{Zn}$ & 600 & \\
\hline
\end{tabular}


The compost used corresponded to three-month-old mature compost, which was provided by a full-scale aerobic composting plant located in Brno-Cernovice (Czech Republic). The characteristics of the compost used are shown in Table 2.

The commercial compost was sieved through a $5 \mathrm{~mm}$ sieve before it was added to the mixture. The manufactured pieces were cut into smaller ones and vacuum-dried at $40.0^{\circ} \mathrm{C}$ $\left( \pm 2^{\circ} \mathrm{C}\right)$ for $72 \mathrm{~h}$ before the experiments. The disintegration experiments were carried out twice with seven types of samples. In addition, a reactor containing wet synthetic material without plastic pieces but with cellulose filter paper was prepared (reactor No. 8 - reference mixture).

The plastics and reference materials were used in the same form, that is, both had a surface of $25 \mathrm{~mm} \times 25 \mathrm{~mm}$. A mass of $7.0 \mathrm{~g}$ of plastic pieces (with the exception of sample number 1 , the mass of which was $3.45 \mathrm{~g}$ ) was mixed with $583 \cdot 10^{-3} \mathrm{~kg}$ of wet synthetic material and put in a polypropylene reactor. The polypropylene vessels of $300 \mathrm{~mm} \times 200 \mathrm{~mm} \times 100 \mathrm{~mm}$ (length, width, height) were hermetically sealed to avoid excessive evaporation, but they had $5 \mathrm{~mm}$ diameter holes at the center of each $100 \mathrm{~mm}$ side for air exchange. The initial volume of the mixture was approximately $90 \%$ of the volume of the reactor. In Table 1, the initial weights of synthetic material and the corresponding amounts of plastic added to each reactor are summarized.

Before the experiments were carried out, the solid synthetic material was checked by means of analyzing volatile suspended solids (VSS) and $\mathrm{pH}$. Proportion rate $\mathrm{C} / \mathrm{N}$ was not calculated according to the Norm CSN EN 14806, because the composting process was conducted properly. The aerobic degradation was carried out in an air circulation oven (composting bioreactor - ECOCELL 22) at a constant temperature of $58.0^{\circ} \mathrm{C}\left( \pm 2^{\circ} \mathrm{C}\right)$. The duration of the incubation was 12 weeks. During this time, moisture, mixing and aeration of the samples were periodically controlled as Norms CSN EN 14806 and CSN EN ISO 20200 prescribe (Table 3). Also the $\mathrm{pH}$ was measured in order to study its evaluation.

Table 3

Task schedule during composting time

\begin{tabular}{|c|c|}
\hline Day of composting & $\begin{array}{r}\text { Task control } \\
\end{array}$ \\
\hline 0 & $\begin{array}{l}\text { 1. Preparation of reactors } \\
\text { 2. Weighing of reactors }\end{array}$ \\
\hline $1,2,3,4,7,9,11,14$ & $\begin{array}{l}\text { 1. Weighing of reactors to control water mass } \\
\text { 2. Addition of water to restore } 100 \% \text { of initial mass } \\
\text { 3. Mixing and manual aeration }\end{array}$ \\
\hline $8,10,16,18,21,23,25,28$ & $\begin{array}{l}\text { 1. Weighing of reactors to control water mass } \\
\text { 2. Addition of water to restore } 100 \% \text { of initial mass }\end{array}$ \\
\hline 30 & $\begin{array}{l}\text { 1. Weighing of reactors to control water mass } \\
\text { 2. Addition of water to restore } 80 \% \text { of initial mass } \\
\text { 3. Mixing and manual aeration }\end{array}$ \\
\hline From day 30 to 45 : twice a week & $\begin{array}{l}\text { 1. Weighing of reactors to control water mass } \\
\text { 2. Addition of water to restore } 80 \% \text { of initial mass }\end{array}$ \\
\hline 45 & $\begin{array}{l}\text { 1. Weighing of reactors to control water mass } \\
\text { 2. Addition of water to restore } 80 \% \text { of initial mass } \\
\text { 3. Mixing and manual aeration }\end{array}$ \\
\hline From day 45 to 60 : twice a week & $\begin{array}{l}\text { 1. Weighing of reactors to control water mass } \\
\text { 2. Addition of water to restore } 80 \% \text { of initial mass }\end{array}$ \\
\hline From day 60 to 90 : twice a week & $\begin{array}{l}\text { 1. Weighing of reactors to control water mass } \\
\text { 2. Addition of water to restore } 70 \% \text { of initial mass }\end{array}$ \\
\hline
\end{tabular}


After a 12-week composting period, the seven composts obtained were characterized by determining their final mass. Each compost sample was dried at $58.0^{\circ} \mathrm{C}\left( \pm 2^{\circ} \mathrm{C}\right)$ until a constant mass was obtained and then sieved with the objective of separating the remaining plastic pieces greater than $2 \mathrm{~mm}$. The recovered fragments were washed with distilled water, dried at $40.0^{\circ} \mathrm{C}\left( \pm 2^{\circ} \mathrm{C}\right)$, and weighed (Precisa $4000 \mathrm{C}$ ) for calculating the corresponding disintegration degree $(\mathrm{D})$ :

$$
D=\frac{M_{i}-M_{r}}{M_{i}} 100
$$

where: $M_{i}$ corresponds to the initial dry mass of plastic material and $M_{r}$ represents the dry mass of the recovered plastic material after composting and sieving.

Monitoring of the composting process and the resulting compost products are essential to determine whether the biodegradable/compostable plastic bags used are biodegradable/compostable and whether they have a detrimental effect on either the composting process or the compost product.

In order to validate the disintegration results, the volatile solids decreasing $(R)$ and the variability of the disintegration degree were calculated:

$$
R=\frac{\left[m_{i}(D M)_{i}(V S)_{i}\right]-\left\lfloor m_{f}(D M)_{f}(V S)_{f}\right\rfloor}{\left[m_{i}(D M)_{i}(V S)_{i}\right]} 100
$$

where $m_{i}$ denotes the initial mass of the wet synthetic material before composting, $(D M)_{i}$ is the initial dry mass of synthetic waste (as \% of total mass) and $(V S)_{i}$ represents the volatile solids of the initial synthetic material (as percentage of $D M$ ). The term $\mathrm{m}_{\mathrm{f}}$ corresponds to the final dry mass of the obtained compost, $(D M)_{f}$ represents the final dried mass of compost (as \% of total mass) and $(V S)_{f}$ is the volatile solids value of the obtained compost (as $\%$ of $D M$ ).

\section{Results and discussion}

\section{Monitoring and control of composting experiments}

In order to verify that the initial synthetic material was adequate for carrying out the composting reaction, some parameters such as dry mass (or moisture) and volatile solids were previously determined for each reactor. The percentage of dry mass was adequate as the relevant Norms recommend $41.6 \%$. The average content of volatile solids was $88.57 \%$. $\mathrm{C} / \mathrm{N}$ was not measured because the composting process was conducted properly.

The composting reaction was periodically controlled by measuring the temperature and odour and by determining the $\mathrm{pH}$ and the content of moisture of each reactor.

Further verification of the correct course of the composting process can be conducted by means of $\mathrm{pH}$ (as stated in the CSN EN 14806 Norm). For the observation and control of the composting substance $\mathrm{pH}$ papers were used. The monitoring was carried out regularly during the entire composting process. Figure 1 shows the $\mathrm{pH}$ variation of each reactor over time. The observed $\mathrm{pH}$ changes correspond to the theoretical evaluation following the Norm CSN EN 14806. 


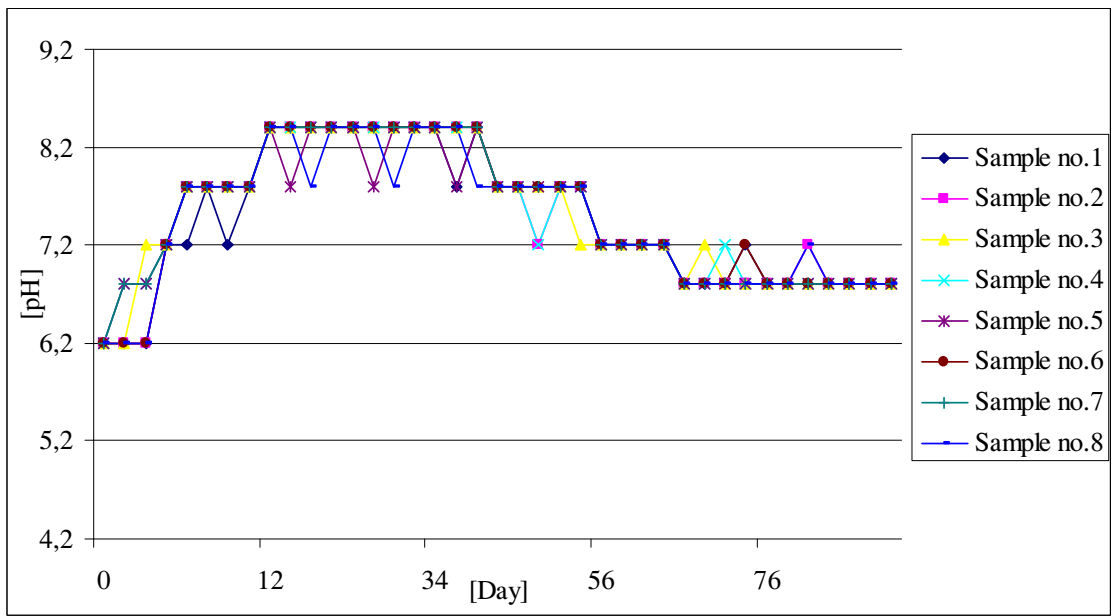

Fig. 1. $\mathrm{pH}$ variation with respect to time during the composting period

\section{Temperature profile}

The temperature was maintained at $58.0^{\circ} \mathrm{C}\left( \pm 2.0^{\circ} \mathrm{C}\right)$ as it is shown in Figure 2. During the period of composting, the temperature decreased below $57^{\circ} \mathrm{C}$ because of the mixing and aeration of the samples. The temperature increased maximum up to $58.8^{\circ} \mathrm{C}$.

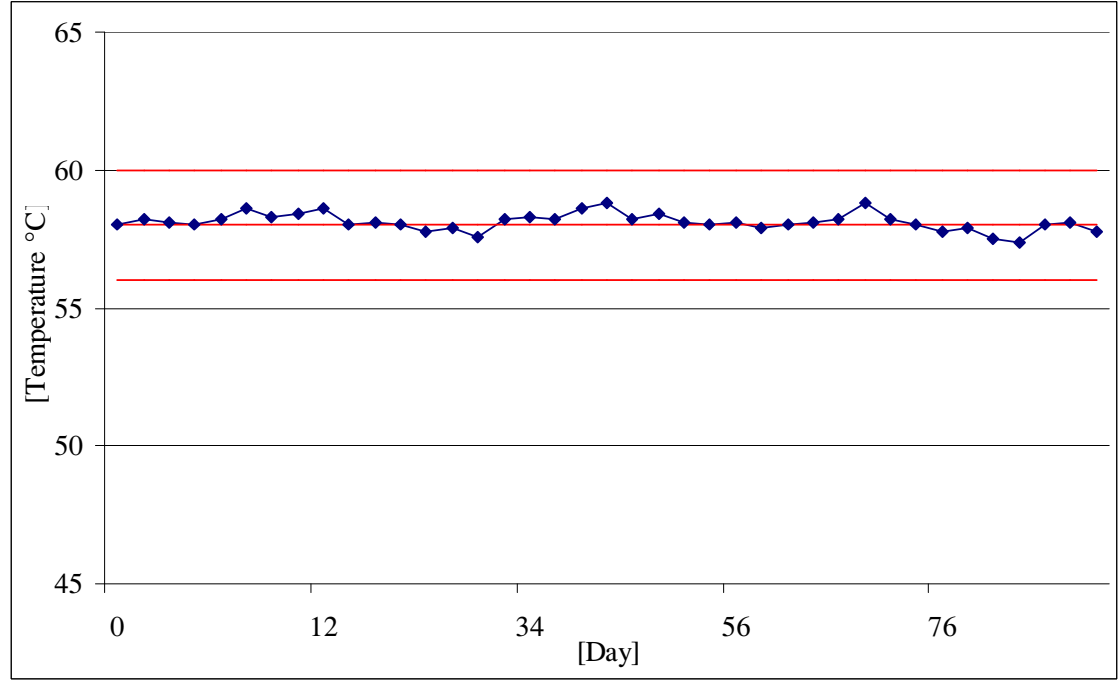

Fig. 2. Temperature variation with respect to time during the composting period

The temperatures in the drying oven ECOCELL (with air circulation) were recorded regularly during the entire course of the experiment. Despite the CSN EN 14806 Norm enables to terminate the temperature measurement after 45 days, in our experiment the 
temperature was measured for the period of 12 weeks. On the basis of the measured figures, a temperature profile was created (Fig. 2).

\section{Control of humidity}

Water content is an important factor affecting microbial activity in composting and ultimately affects the rate of degradation. Ghorpade et al have reported that moisture content may fall $20 \div 56 \%$ [13]. Losses of water were observed in all of the reactors throughout the composting period. In our case, distilled water was added to the reactors in order to maintain the optimal percentage of moisture. After 12 weeks of composting, each compost sample was characterized.

During the experiment, as stated in the CSN EN 14806 Norm, it is necessary to control the humidity in order to verify the adequate course of the composting process. In our test the humidity control was conducted according to Kalina [14]. The humidity was measured by a preliminary test periodically during the entire course of the experiment. The composting material was squeezed in hand as firmly as possible. Under the adequate humidity conditions no water shall occur between the fingers and when the palm is opened the material must hold together.

\section{Odour}

Following the CSN EN 14806 Norm the odour was observed during the composting process. As stated in the Norm a precise consequence of specific odours can be observed during the process. The sequence of recorded odours in the test was as follows: during the first two days the synthetic waste showed acid odour, approximately from day 8 the odour altered into ammonia and from day 20 no odours (ammonia or acid) were perceptible.

\section{Disintegration calculation}

Table 4 presents the exact amounts of plastic pieces before and after composting from each reactor, as well as their corresponding disintegration degree $(D)$, calculated according to Eq. (1).

Amounts of plastic pieces before and after composting and biodisintegration degree $(D)$

\begin{tabular}{|c|c|c|c|}
\hline Sample & $\mathbf{M}_{\boldsymbol{i}}[\mathbf{g}]$ & $\mathbf{M}_{\boldsymbol{r}}[\mathbf{g}]^{*}$ & (D) decomposition [\% $^{*}$ \\
\hline 1 & 3.45 & 3.7 & 0 \\
\hline 2 & 7.02 & 7.5 & 0 \\
\hline 3 & 7.03 & 7.2 & 0 \\
\hline 4 & 7.01 & 0.03 & 99.6 \\
\hline 5 & 7.02 & 0 & 100 \\
\hline 6 & 7.01 & 0.009 & 99.9 \\
\hline 7 & 7.02 & 0 & 100 \\
\hline 8 & 7.02 & 0 & 100 \\
\hline
\end{tabular}

*average value

In samples 4, 5, 6 and 7, more than $90 \%$ of the initial plastic material was degraded. In particular, the disintegration degree of samples 5, 7 had an average value of $100 \%$, while the average values obtained for samples 4 and 6 were 99.6 and $99.9 \%$, respectively. This 
fact could be explained because this bioplastic material contains a starch in its composition. Because starch is a highly biodegradable component, the material was more available to microorganisms, which improved the degradation. These results are in accordance with those reported by Gattin et al [15] where PLA-starch extruded films were subjected to composting in similar conditions for 45 days. The final mineralization percentage was $71 \%$, which was facilitated by the presence of starch. The biodisintegration degree of PLA-corn did not depend on the shape and/or size of the manufactured pieces because the behavior of all of the tested pieces was the same [15].

\section{Validation of disintegration tests}

In order to validate the results of the disintegration experiments of all samples, the volatile solids decreasing (R) was calculated for each reactor according to Eq. (2). According to the Norms CSN EN ISO 20200 and CSN EN 14045, the results of R can be considered valid as all the calculated values for the seven reactors (including reference mixture without plastic pieces) were greater than $30 \%$.

\section{Conclusions}

The operational parameters showed that the test was valid. The cellulose filter paper (CFP) completely degraded after 10 days (reactor no. 8 - reference mixture), implying that it was fully biodegraded $(100 \%)$ and that the conditions required for biodegradation to occur in a sampling environment were present. No breakthrough in disintegration was observed for samples 1, 2, and 3 during 12 weeks of composting. After 12 weeks of composting in a laboratory-scale test, the test material still remained completely intact. The samples did not show any significant biodegradation or any visual changes and were not broken into smaller pieces or easily crumbled when touched. The surface was smooth, and there were no pinholes observed on the surface after the test. Sample 2 showed no decrease in color intensity, the pigment was still rich. Samples 1 and 3 showed a visible change in pigmentation.

It was found that the weight loss of the degraded material strongly depends on the specific kind of biodegradable plastic. The disintegration of the certified compostable plastic bags (samples 4, 5, 6, and 7) proceeded very well. After 6 weeks of composting in the laboratory-scale test, the different test materials seemed to completely disappear (sample 4 seemed to completely disappear after 4 weeks). This was confirmed at the end of the test. No single piece of sample 5 or 7 could be retrieved at the end of the test. The mass of sample 4 was measured to be $0.03 \mathrm{~g}$ after finishing the test, while the mass of sample 6 was measured to be $0.009 \mathrm{~g}$.

From this test, it can be concluded that the four certified compostable plastic bags showed a complete level of disintegration during the 12-week composting laboratory-scale test. Test material 1,2, and 3 remained completely intact at the end of the test. The experiment did not yield the anticipated results, despite the fact that many studies have confirmed the biodegradability of the plastics samples.

After finishing the test a chemical analysis of the substrate will be carried out. The aim of the chemical analysis is to find out the influence of the qualitative parameters of the substrate after the biodegradation process of the samples. Within the chemical analysis, the 
content of the hazardous elements $(\mathrm{Cd}, \mathrm{Ni}, \mathrm{Pb}, \mathrm{As}, \mathrm{Cr}, \mathrm{Mo}$, and $\mathrm{Hg})$ and the content of nutrients $(\mathrm{Ca}, \mathrm{P}$, and $\mathrm{K})$ will be analyzed.

Systematic research to investigate the effects of composting conditions on the degrability of degradable/biodegradable plastic should be performed in the future.

\section{Acknowledgments}

This study was supported by the Research plan No.MSM6215648905 "Biological and technological aspects of sustainability of controlled ecosystems and their adaptability to climate change“", which is financed by the Ministry of Education, Youth and Sports of the Czech Republic.

\section{References}

[1] Sivan A. New perspectives in plastic biodegradation. Curr Opin Biotechnol. 2011;22(3):422-426.

[2] Iovino R, Zullo R, Rao MA, Cassar L, Gianfreda L. Biodegradation of poly(lactic acid)/starch/coir biocomposites under controlled composting conditions. Polym Degrad Stab. 2008;93:147-157.

[3] Mohee R, Unmar G. Determining biodegradability of plastic materials under controlled and natural composting environments. Waste Manage. 2007;27:1486-1493.

[4] Leejarkpai T, Suwanmanee U, Rudeekit Y, Mungcharoen T. Biodegradable kinetics of plastics under controlled composting conditions. Waste Manage. 2011;31:1153-1161.

[5] Mohee R, Unmar GD, Mudhoo A, Khadoo P. Biodegradability of biodegradable/degradable plastic materials under aerobic and anaerobic conditions. Waste Manage. 2008;28:1624-1629.

[6] Kale G, Kijchavengkul T, Auras R, Rubino M, Susan E. Selke, Singh S. Compostability of bioplastic packaging materials: An overview. Macromol Biosci. 2007;7:255-277.

[7] Kale G, Auras R, Singh S, Narayan R. Biodegradability of polylactide bottles in real and simulated composting conditions. Polym Test. 2007;26:1049-1061.

[8] Guillet J. Plastics and the Environment. Degradable Polymers: Principles and Applications. London: Chapman and Hall; 1995.

[9] Vikman M, Karjomaa S, Kapanen A, Wallenius K, Itävaara M. The influence of lignin content and temperature on the biodegradation of lignocellulose in composting conditions. Appl Microbiol Biotechnol. 2002;59:591-598.

[10] Nakasaki K, Ohtaki A, Sato N, Kubota H. Effects of temperature and inoculum on the degradability of biodegradable plastic during composting. Organic Recovery and Biological Treatment (ORBIT). 1997;205-208.

[11] Venelampi O, Weber A, Rönkko T, Itävaara M. The biodegradation and disintegration of paper products in the composting environment. Compost Science and Utilization. 2003;11(3):200-209.

[12] De Wilde B, Boelens J. Prerequisites for biodegradable plastic materials for acceptance in real-life composting plants and technical aspects. Polym Degrad Stab. 1997;59:7-12.

[13] Sarasa J, Gracia J, Javierre C. Study of the biodisintegration of a bioplastic material waste. Biores Technol. 2009;100:3764-3768.

[14] Kalina M. Composting and Care for Land. Prague: Grada Publishing; 2004 [In Czech].

[15] Gattin R, Copinet A, Bertrand C, Couturier Y. Biodegradation study of a starch and poly(lactic acid) co-extruded material in liquid, composting and inert mineral media. International Biodeterioration and Biodegradation. 2002;50(1):25-31.

[16] ČSN EN 14806 Norm "Packaging - Preliminary evaluation of the disintegration of the packaging materials under simulated composting conditions in a laboratory scale test" [In Czech].

[17] ČN EN ISO 20200 "Plastics - Determination of the degree of disintegration of plastic materials under simulated composting conditions in a laboratory-scale test" (ISO 20200:2004). 


\title{
BADANIE BIODEGRADACJI ROZKLADALNYCH/BIODEGRADOWALNYCH TWORZYW SZTUCZNYCH W KONTROLOWANYCH WARUNKACH KOMPOSTOWANIA
}

\begin{abstract}
Abstrakt: Celem badań było określenie degradacji/biodegradacji ,,jednorazowych" plastikowych toreb dostępnych na rynku, które są oznaczone jako degradowalne/biodegradowalne, jak również toreb certyfikowanych jako nadające się do kompostowania. Badane materiały są dostępne w sieci sklepów w Czechach oraz w Polsce. Badaniu poddano siedem próbek. Jedną z nich była jednorazowa torba wykonana $\mathrm{z}$ folii HDPE ( polietylenu łatwo degradowalnego) z dodatkiem TDPA (powodującego całkowitą degradację folii-polietylenowej). Badano też torby wykonane z różnymi dodatkami, co powodowało ich rozkład w określonym czasie. Testy zostały przeprowadzone w kontrolowanych warunkach kompostowania. Stopień rozkładu określono za pomocą zmodyfikowanej wersji normy ČSN EN 14806 „Opakowania - Ocena wstępna rozpadu materiałów opakowaniowych w symulowanych warunkach kompostowania w badaniach w skali laboratoryjnej” oraz zmodyfikowanej wersji normy ČSN EN ISO 20200 „Tworzywa sztuczne - Oznaczanie stopnia rozpadu tworzyw sztucznych w symulowanych warunkach kompostowania w skali laboratoryjnej” (ISO 20200:2004). Głównym celem badań było określenie, czy jednorazowe torby ulegają degradacji/biodegradacji czy nie.
\end{abstract}

Słowa kluczowe: degradacja, biodegradacja, kompostowanie, kontrolowane warunki kompostowania 